\title{
Fuel Subsidy Removal in Nigeria: Socio-Religious and Value Implications Drawn from the Theistic Humanism of Professor Dukor
}

\author{
Chinyere T. Nwaoga ${ }^{1}$, K. C. Ani Casimir ${ }^{2}$ \\ ${ }^{1}$ Department of Religion, Centre for Entrepreunenal Research, University of Nigeria, Nsukka, Nigeria \\ ${ }^{2}$ Department of Philosophy, Institute of African Studies, University of Nigeria, Nsukka, Nigeria \\ Email: nwaogachichi@yahoo.com, cepperngo@yahoo.com
}

Received December $24^{\text {th }}, 2012$; revised January $20^{\text {th }}, 2013$; accepted February $7^{\text {th }}, 2013$

\begin{abstract}
Nigeria is a country blessed with abundant human and material resources. Pre-independent Nigeria had agriculture as the major foreign exchange and revenue earner. Other alternative revenue earners such as agricultural and mineral resources were explored and their proceeds used to support and foot the bill of government expenditures. Immediately the first oil field was discovered in 1956 at Olobiri in the Niger Delta, other alternative sources of revenue for Nigeria were abandoned and crude oil became the determinant of Nigeria's mono-economic status and the sole basis of all socio-economic transaction within and outside the country. The issue of appropriate pricing of petroleum products and the removal of government's subsidy on petroleum price became a thorny controversial public policy issue. Successive governments, including the current President, have grappled with this problem of whether to remove the subsidy or not, without coming to a publicly endorsed solution to the debate. The last fuel subsidy removal on 1st January, 2012 sparked an uprising that almost led to a revolution. The thrust of the study is to examine the causes of the fuel subsidy removal, to identify the benefits of fuel subsidy removal, to describe the effects of the subsidy removal, and the socio-religious implications of the removal of fuel subsidy to the citizens of Nigeria. It is in the context of these socio-religious that one discovers the relevance of Professor Dukor theistic humanism and its implied need for African values to be applied to governance in the 21 st century. The debate surrounding the subsidy removal and the subsidy scam running into trillions of Naira of stolen funds by independent marketers of petroleum products revolve around corruption and a bad commentary about how ethical African vales have been removed from public governance and the management of public resources. After pointing out these socio-religious implications for the Nigerian ethical and value re-orientation, the paper went ahead to recommend some ways of managing the subsidy money for the development of the country.
\end{abstract}

Keywords: Theistic Humanism; African Values; Socio-Religious Implications; Corruption; Subsidy Removal; Scam; Benefits; Effects

\section{Introduction-Background to the Study}

In Nigeria, the issue of appropriate pricing of petroleum product has always been a thorny controversial government policy issue for the past 30 years. Successive governments, including that of the current President Goodluck Ebele Jonathan, have grappled with this problem to no avail. Like most other issues that affect the citizens, there seems to be no other generally acceptable solution to the teething problems because of the interplay of politics and economic maneuvers. In the history of Nigeria, subsidy removal implemented by subsequent governments and the outcome of the action had negative effects on the integrity of the regimes. According to Oxford Advanced Learners Dictionary (1990), subsidy is defined as "the money that is paid by a government or organization to reduce the cost of services or of producing goods so that their prices can be kept low". The essence of having subsidy in place for products and services is that it has direct positive impact on poverty reduction in the lives of the poor masses who could ill afford high prices in the light of the harsh conditions under which developing countries are reeling under globalization. Many subsidies are made by the government in form of subventions to aid some businesses, produce essential commodities that would otherwise reduce prices that are patently unaffordable. In some developing countries like Nigeria, which has a mono-economy; petroleum is the main stay of foreign exchange. The issue of subsidy adjustment is highly a sensitive matter. The major focus or thrust of this work is to discuss the socio-religious implication of the fuel subsidy removal in Nigeria. According to Reymond (2012) in toned that, for many Nigerians, the fuel subsidy removal is merely a symptom of deeper-rooted problems that exist within the system with a stagnant economy, high levels of corruption, little or no investment in health, education or other social amenities, and weak infrastructure, the reaction of the population did not come as a surprise.

According to Achebe (1983) African political, social, religious and economic development is fully and squarely the failure of leadership. Though, government has insisted that the reason for the fuel subsidy removal is not aimed at causing hardship on Nigerians but, rather, it is for the benefit of all the citizens. The Federal Government has maintained that fuel subsidy will help to open up other sectors for growth and in- 
vestment to take place properly. The last fuel subsidy removal which took place on 1st January, 2012 sparked an uprising that almost led to a revolution. This ill-timed fuel subsidy removal regrettably came at the peak of religious festivities. It was widely rejected by all including religious leaders who condemned out rightly the actions of the government. Both the Christian and Muslim clerics condemned it, though they tactically helped to diffuse tension by preaching the merits and demerits of the fuel subsidy removal.

\section{History of Fuel Subsidy Removal in Nigeria}

Nigeria is a nation endowed with abundant human and material resources. In the early 1950's and at independence, Agriculture was the chief foreign exchange earner of this nation. Other mineral deposits like coal, Tin and agricultural resources, examples rubber, cotton etc, were explored, while their proceeds used to support the governmental expenses. Immediately crude oil deposit was discovered in (1956) at Olobiri Delta state, attention was then diverted to oil exploration and exportation. As a result of this, huge foreign exchange earnings and reserve rose to unprecedented promising level. Soon after, other variable areas of reserve earning were abandoned. Fuel now became the determinant of our economic transactions with the rest of the world. Nowadays, the economy of the country depends mainly on crude oil.

According to Obasi (2003), he asserted that Petroleum products account for $95 \%$ of Nigeria's foreign exchange earnings. The government has all along been subsidizing the pump price of petroleum products, such as petrol, kerosene, and diesel to cushion the effect of poverty and underdevelopment. Recently, following the global economic downturn in most economies, the amount paid by the government to subsidize goods and services were gradually withdrawn to prevent serious economic failure. In order to avert the total collapse of the economy, the Federal Government decided to subsidize fuel. Table 1 shows the history of fuel subsidy removal in Nigeria from 1973-till date, (2012).

Finally, on January 1st 2012, Nigerians got another wonderful New Year gift when it was again hiked to N141 per liter. After much protest, and a week old NLC strike that shut down the economy of Nigeria, the government reduced the price on January 16th, 2012, to N97 per liter, and that remains the current price till date.

\section{Reasons for Fuel Subsidy Removal}

Age-long reasons for fuel subsidy removal have been given by the previous and present administrations. The government has enumerated so many reasons, one of which is the "cabal" issue. According to Wikipedia, the free encyclopedia, a cabal is a group of people conspiring in plotting an illegal or evil activity. Also, they are few corrupt individuals that are united to promote their private interest. Therefore, the government strongly believes that this group is responsible for large scale corruption in the downstream oil sector. These groups of people have disregarded the value of Nigerian culture. According to Dukor (2010), the value of culture in Nigeria goes beyond ethnic and norms, for him, values are embedded in African culture of which corruption is a direct opposition and against norms and values. It is pertinent at this point to enumerate some of the reasons for fuel subsidy removal. They include social, economic,
Table 1.

One: showing the history of fuel subsidy removal with different rates from different Governments in Nigeria (1973-2012). Source: Nairaland Forum, 2012.

\begin{tabular}{|c|c|c|c|}
\hline Names of the leaders & Year & Amount & Percentage (\%) \\
\hline Gowon & 1973 & $6 \mathrm{k}$ to $8.5 \mathrm{k}$ & $40.8 \%$ \\
\hline Murtala & 1976 & $8.45 \mathrm{k}$ to $9 \mathrm{k}$ & $0.59 \%$ \\
\hline Obasanjo & 1978 & $9 \mathrm{k}$ to $15.3 \mathrm{k}$ & $70 \%$ \\
\hline Shagari & 1982 & $15.3 \mathrm{k}$ to $20 \mathrm{k}$ & $30.71 \%$ \\
\hline Babangida & 1986 & $20 \mathrm{k}$ to $39.5 \mathrm{k}$ & $97.5 \%$ \\
\hline Babangida & 1988 & $39.5 \mathrm{k}$ to $42 \mathrm{k}$ & $6.33 \%$ \\
\hline Babangida & 1989 & $42 \mathrm{k}$ to $60 \mathrm{k}$ & Private vehicle \\
\hline Babangida & 1989 & $60 \mathrm{k}$ (Uniform Price) & $42.86 \%$ \\
\hline Babangida & 1991 & $60 \mathrm{k}$ to $70 \mathrm{k}$ & $16.67 \%$ \\
\hline Shonekan & 1993 & $70 \mathrm{k}$ to $\mathrm{N} 5$ & $614 \%$ \\
\hline Abacha & 1993 & $\mathrm{~N} 5$ to $3.25 \mathrm{k}$ & $-35 \%$ \\
\hline Abacha & 1994 & $\aleph 3.25 \mathrm{k}$ to $\$ 15$ & $361.54 \%$ \\
\hline Abacha & 1994 & 15 to 11 & $-26.67 \%$ \\
\hline Abubakar & 1998 & $\$ 11$ to $\$ 25$ & $127.27 \%$ \\
\hline Abubakar & 1999 & $\approx 25$ to $\$ 20$ & $-20 \%$ \\
\hline Obasanjo & 2000 & $\$ 20$ to $\$ 30$ & $50 \%$ \\
\hline Obasanjo & 2000 & $\$ 22$ & $-10 \%$ \\
\hline Obasanjo & 2002 & $\$ 22$ to 26 & $18.18 \%$ \\
\hline Obasanjo & 2003 & $\$ 26$ to $\$ 42$ & $23.08 \%$ \\
\hline Obasanjo & 2004 & $\$ 50$ & $19.05 \%$ \\
\hline Obasanjo & 2004 & $¥ 65$ & $30 \%$ \\
\hline Obasanjo & 2007 & $\$ 75$ & $15.38 \%$ \\
\hline Yar'Adua & 2007 & N65 & $-15.38 \%$ \\
\hline Jonathan & 2012 & $\$ 138$ to $\$ 250$ & $112.31 \%$ to $284.62 \%$ \\
\hline
\end{tabular}

security, health, infrastructure, transportation, communication, education, technology, job creation, power supply, poverty alleviation and other social amenities etc.

\section{To Curb Corruption in the Oil Sector}

Corruption is one of the major problems affecting every sector of Nigeria. According to Igwe (2010: p. 13), "corruption has tragically devastated African societies and made millions of people destitute. From South Africa to Egypt the tentacles of corruption reach everywhere. From the offices of presidents and prime ministers to the smallest administration unit of government corruption is everywhere". Majority of the citizens however are eager to see that corruption is eradicated in Nigeria even though it looks intractable. Also Juliet 2012, quoting Diezeani in leadership newspaper of 11th January 2012, "corruption has been one of the burning issues in Nigeria". It is 
asserted by government that only some people benefit from the subsidized fuel. These people, they claim, buy Nigerian refined oil at N65 per liter and smuggle it out to neighboring countries like Chad Republic and Benin Republic, whose fuel products are equivalent to N200 per liter. In a situation whereby the subsidy is removed, corruption would be tackled and masses are likely to benefit from their oil once again. The changes in the fuel marketing and distribution network will be checked as several importers and independent marketers, which hitherto exploited government subsidies, will be eliminated from the fuel supply chain.

\section{To Create Jobs for the Citizens}

President Goodluck Jonathan had job creation as one of his transformation agendas. The term fuel subsidy entails wealth creation as it will enhance income, this income, will be translated into more savings and investment and of course greater income. This savings and investments are what translate to development and development leads to fuel subsidy removal of Jonathan's administration. He believed that, creating jobs will help transform the entire economy. According to Abiola in Tell Magazine of 2012, President Goodluck, during a nationwide broadcast on January 1st, 2012, said "the aim of the subsidy removal was meant to create massive employment for the teeming unemployed youths of Nigeria. Unemployment has become a major illness ravaging the social fabrics of Nigeria. Graduates of different categories are storming the labour market without any commensurate job opportunity. In fact, unemployment has dragged the idle minds of many youths into so many social ills to make ends meet. Ituma (2008: p. 23) observed that "corruption in Nigeria cannot be adequately handled if youth's development is not adequately addressed". Therefore, job creation is one of the responsibilities of a good government. Nigerian government decided to increase the fuel price to enable them to get more money, which will be channeled into industrialization whereby employment opportunities will be made available for the youths.

\section{Provision of Steady Power Supply}

Power and energy remain the most vital infrastructure needed to power Nigeria's development. According to Ngozi (2004: p. 134), the availability of uninterrupted electricity is a sin quo non for running of businesses in Nigeria. The manufacturing sector, agro - based industries etc need energy to carry out their businesses. Ngozi (2004), availability of consistent power will lower the cost of production, as companies and individuals engaged in small and medium scale businesses would not have to rely on generating sets, with attendant high cost of fuel (petrol and diesel). Therefore, one major reason for fuel subsidy according to Jonathan's administration is that, when power is readily accessible and cheap, business concerns will make more profits and will run at optimum capacity; thereby generating more money for government through tax, as well as employing more people.

\section{Poverty Eradication and Alleviation}

Poverty is a big problem confronting the third world countries of which Nigeria falls in. Chuta (2004: p. 56) listed poverty as one of the principal causes of intra-communal crises, armed robbery and other social vices. The same was acknowledged by Abdulsalami (2009: p. 327) when he reported that the Sultan of Sokoto Alhaji Saad Abubakar II, opined that "poverty contributed to many crises ravaging the state of Nigeria". According to the U.N.O. any group of people that lives by less than one dollar per day is poverty stricken. Recently, the World Bank had it that more than 100 million Nigerians lives on less than one dollar per day. All these indices fueled the agitation for the removal of fuel subsidy by the Nigeria government. According to Ezeani, (2012: p. 37).

The progress towards the eradication of poverty and hunger in Nigeria has been slow. Although the Gross Domestic Product (GDP) and the rate of economic growth have improved over the last decade, this has not led to more jobs or less poverty. For example, the GDP at 1990 constant prices increased from $6.03 \%$ in 2006 to $6.60 \%$ in 2007 and fell slightly to $5.98 \%$ in 2008 . The "GDP grew by $6.96 \%$ and $7.87 \%$ in 2009 and 2010" (NBS, 2010: p. 8). The percentage of the population living below the poverty line increased significantly from $27.2 \%$ in 1980 to $69 \%$ in 2010. It is obvious that poverty is one of the major problem facing Nigerians, unless poverty is tackled Nigerian will continually be underdeveloped.

In line with the above, it is worthy to note that the removal of fuel subsidy will help to reduce poverty in Nigeria if the money realized from it will be used judiciously for the common masses in the country.

\section{Benefits of Fuel Subsidy Removal in Nigeria}

If there is one positive thing that has come out of this experience for Nigerians, it is that it has united Nigerians irrespective of class, ethnic, regional and religious divides. It has brought Muslims and Christians from the north and South together at a time when the country was going through unrest due to regional and religious differences. Many are beginning to understand that these artificial divides are politically motivated and based on sentiments that can only further divide the country. In addition, for the first time ever, young men and women, the unemployed and employed across board were chanting the same tune. The masses spoke against real issues that affect all citizens and holding leaders accountable for their activities which was one of the ways to achieve meaningful socio- economic development, stability and lasting peace in the country. These benefits include, the creation of a better foreign investment climate and infrastructural development.

\section{Improvement of the Economy by Creating Favorable Climate for Investment}

There is no serious investor that will like to plunge his capital into a regulated oil industry. It is only when there is full deregulation that it can attract investors to build refineries and develop the other downstream sectors. For the idea of saying no deregulation is like "wanting to eat our cake and still have it". Also, as its removal creates conducive climate for investment, it will give room for a competitive market, and the result of such is a continual drop in prices of petroleum products to the delight of Nigerians. Take for instance, the telecommunication sector; due to the fact that it was deregulated, we are now left with several options from where to choose the most suitable 
and preferred network services.

\section{Infrastructural Development}

The savings accruing from the withdrawal of oil subsidy, could now be fully channeled to key sectors of the national economy, like education, steady water supply, electricity, good road, good healthcare services, agriculture etc. which virtually have been receiving little attention in the past budget allocations. These can help enhance the standard of living of Nigerians and will also open more ways of improving the economy of Nigerians.

\section{Negative Effect of Fuel Subsidy Removal in Nigeria}

Effect according to English mini dictionary is defined as "a change produced by an action or other cause". Thus, it involves the outcome or implication of an action which can be negative or positive results or outcome of an action but involves or entails both. The effects of the fuel subsidy are as follows.

\section{Increase in the Cost of Living}

Usually, whenever there is increase in pump price of fuel it is immediately followed by increase in other services. The effect of the subsidy removal extended to other social spheres of life, ranging from increase in school fees, transportation fare; house rent etc. According to Kalu (2011), fuel as an industrial commodity is also important to other sectors of man's activities. Removing the oil subsidy is like removing two square meals from the tables of over one hundred and forty million Nigerians. Immediately the subsidy was removed and the price of fuel increased, there was multiple increases of goods and services in Nigeria, e.g., there was astronomical increase in tuition fees, transportation, house rents, food items, and other basic commodities. This gave room for multiple increases of goods and services in Nigeria.

\section{Mistrust of the Government}

Nigerians are no longer comfortable with the promises of the Government. During the Eight (8) years of Obasanjo's administration the pump price of fuel was increased by the Government promising to improve the Nation's economy, infrastructure and create jobs for the youths. But till date, little or nothing was achieved. According to (Adogah, 2011), he maintained that this is a typical scene of how Government pays the people in return after removing the partial subsidies in the past. Because of this, the people now had reasons to mistrust what the Government said concerning fuel subsidy removal in Nigeria. According to Onoho, in Guardian newspaper (2012), one of the analogies in public policy is illustrated by the statement of Mario Soares upon his assumption for the second time in office as the Prime Minister of Portugal in 1983. He told his countrymen that his government will be austere, uncompromising, and unpopular. According to him, this is what he required to achieve the economic recovery of Portugal'. Unfortunately, this was against the manifesto of the Goodluck's administration prior to his coming into office; he had in his manifesto that the price of fuel will be reduced from N65.00 to N40.00. This made a lot of people to vote for him. The President was a beneficiary of the civil society struggle for good governance but with the recent increase in fuel price, he has made his government unpopular and some people cannot trust his government again. Though Nigeria is one of the richest oil producing countries in the world, but $70 \%$ of its citizens are living below poverty line.

\section{Increase in Crimes/Civic Disturbance}

There was insecurity, robbery, bomb blast, kidnapping, hostility and many others among the citizenry during and after the removal of fuel subsidy in Nigeria. Suffice to say that kidnapping has never been part of Nigerian culture, but due to hardship, some people decided to employ themselves by indulging in different types of crimes. This therefore, increases the crime rate in Nigeria which destroys the image of the Nation both inside and outside the country. According to Adeola (2012), Nigeria is one of the highest rated corrupt Nations in the World.

\section{The Looming Insecurity Problem}

Security is paramount for the sustenance of any society. Ngozi (2004: p. 137) noted that, the lives and property of the citizens and other residents must be protected by the government, because no nation can survive in a state of anomie. Since the inception of the present democracy in 1999, the Nigeria nation has been bedeviled with a lot of security crisis. These include armed robbery, ritual killings, religious riots, community and tribal wars, kidnapping and outright sabotage of Nigerian economy through the destruction of oil installations by Niger Delta Militants. Therefore, in other to put an end to this already problems of insecurity in the country became one major tenet for fuel subsidy removal according to Goodluck Jonathan' administration.

\section{Increase in Poverty}

There is no firm meaning of poverty because it is a physical matter and relative in nature. Ngozi (2004) quoting Kennet Gailbraith, those affected by poverty have: 1) Insufficient food; 2) Poor clothing; and 3) They live in crowded and dirty shelter. Nevertheless, the believing is that, fuel subsidy removal, will overhaul and complicate the pattern of living of the populace. The removal will skyrocket the prices of goods and services in the country. From purchasing a car to buying salt and maggi, the story has been the same as even a grandmother that sells firewood has subsidy removal for the excuse of her price increase. So the order of the day became a reign of hardship and pain, especially on the common man who is either unemployed or is seated below the very meager minimum wage.

\section{Widening of the Communication Gap between People and Institutions}

The primary lubricant of social life is communication. In the wake of the fuel subsidy removal, transportation costs skyrocketed to about $250 \%$ and even telecom service providers threatened to increase their tariffs or call rates since most of their activities depends on petrol for their powering. The above scenarios being the case, the communication link between people and institutions was hampered.

\section{Increase in Social Vices}

As a result of the effect of the removal of fuel subsidy, hardship became the order of the day making some people do dirty 
jobs like prostitution; armed robbery etc. Bribery and corruption came on the increase as fraudsters are now hanging all around the streets lying in wait for the next catch. Social vices are on the increase, the safety and well-being of the entire nation is hanging on a balance as Boko-Haram, kidnapping etc. are the order of the day. This was in accordance with what John Kockels, in Dukor (2010). According to him, there is no natural proactivity of men to hurt one another.

\section{Effects of Fuel Subsidy Removal}

Nigeria is a country with multi ethnic groups. These ethnic groups have different cultures, religion, values and norms. Because of these differences, Muslims, especially their fundamentalists perceived it as a ploy by the President who is a Christian to inflict pains on them. The perception has deepened the level of religious tension in the country thereby affecting the possibility of peace and tranquility that this country deserves. If the rejection of subsidy had not gotten opposition from the masses, it would have been broadly gotten from the Muslims on the grounds that their religion is against the west, and the policy of deregulation which predominantly affects Christians generally.

The effect of the removal of subsidy has on religion is the fact that it creates a gap between the two dominant religions and makes the one apprehensive of the other. Since the increase in fuel subsidy, there has been increase in the burning of churches by the so-called Boko Haram groups. The security and peace of the Nation Nigeria is threatened. With this condition of strife, conflicts are imminent and the unity of the country is particularly threatened, contestation still rises over the faulty unification arrangement process of Nigeria and this issue seems to fan the embers of the contestations.

There is no doubt that most of the so called "mushroom" Pentecostal churches, especially those at their infant stage will lose down completely or be affected adversely, loose some or most of its members as a result of the socio-political cum economic effects of this subsidy. Many religious (church) programmes will either stop or be greatly affected due to its economic consequences, hence inability to raise funds for its projects.

Moreover, due to restrictions in movements, church programmes both in and outside the country were highly minimized, because of the hike in transportation and insecurity in the country. Indirectly, the fuel subsidy removal affected people's faith and beliefs. Some people began to question if actually God answers prayers.

\section{Poor Maintenance of Churches/Church Leaders}

The Church is not a business enterprise. According to CBNEDC resource material (2009), a business enterprise is defined as an operating entity within a business environment aimed at making profit, gain from buying and selling of goods and services rendered. From the above definition, the Church is only maintained from offerings, tithes from Church members, Churches are not supported by the Government. Attendance of church members was affected because of the fuel price hike, the impact of these was felt in almost all the churches. Example, reduction in offerings and tithes, which affected the welfare of church workers. Therefore, the aforementioned socioreligious effects and many other affected church activities in the country.

\section{Rise of Religious Tension in the North}

Due to the mixed reaction of Muslims in the North, as a result of the fuel subsidy removal, there was high sense of fear of the unknown for the Christians, because Muslims now see Christians as birds of the same flock, starting from the president. Following the incident of the crisis that strut up, after the elections, there was tensed atmosphere and the possibility of such, repeating itself, for virtually the Muslims dominate in such part of the nation. As soon as the subsidy was removed, the Boko Haram sect ordered the Westerners, Easterners to leave the northern states for them. These subsidy removal mounted religious tension especially in Northern part of Nigeria. The upsurge in civil disobedience widened the fear of insecurity as the Boko Haram sect used the opportunity to increase public terrorist attacks because of the fuel price increase. This public attacks and insecurity hada negative impact on the economic, social, political and religious life of the country, Lawson, (2012).

\section{Impact on Pilgrimage Patronage}

Aside the major pilgrimage visits to Mecca and Jerusalem, there abound numerous local pilgrimage centers. According to Wikipedia, Pilgrimage centers are places where people meet to pray in group to strengthen their religious consciousness. Examples of these pilgrimages include: Fr. Edeh's Monthly pilgrimages at Elele, River State. Fr. Mbaka's weekly Adoration in Enugu, the Pastor David Oyedepo's yearly winners Convention in Ogun State, Conference experience in Lagos, Rev fr Obayi's Friday prayers etc. The expenditure people undertake to feature in these activities is so much that the incidence of fuel price hike will make it much more exorbitant, thus dissuading people from participating. As a result, the noble function of faith strengthening which pilgrimages perform is lost to the occasioned by the removal of fuel subsidy.

\section{Breakdown/Decadence of the Moral Order/Values}

The concept of theistic humanism gives us the two sets of African emanate from the religious beliefs of Africans and affect their behavior in the society. The first set are those ethical or axiological values whereas the second set constitute aesthetic and artistic values that define the non-moral normative values found in African philosophy embedded in folklores, proverbs and wise sayings on one hand and on the other hand are propositions within the kinship or communalistic system (Dukor, 2010: pp. 15-16). The unique concept of African cultural values has a dialectical relationship with theistic humanism as propounded by Professor Maduabuchi Dukor as it is the defining principle of African cultural values and from it springs what he calls the community values of kinship, extended family, communitarianism and social values. At the same time theistic humanism gives rise to the second set known as aesthetic values such as food and work habit, agricultural and architectural values, music, artistic values and celebration of life. He called the first set "community consciousness" while he called the second as "aesthetic consciousness" with both having their roots in "the religious, scientific and existential value" which he called theistic humanism. Both consciousness - the community and the aesthetic-complement and supplement each as they are not exclusive but inclusive in their functional cooperation, collaboration and synergy in maintaining the happiness, peace, security and progress of the African society. 
It is an existential truism that the religious institutions are the custodian of morality, which is largely responsible for the seeming social order enjoyed in other spheres of social life. However, the removal of fuel subsidy has some untold hardship on the people leading to their being left with no option than to avoid calls by their religious leaders to adhere to the moral code. As such, increase in the crime wave, prostitution, drug trafficking and addiction, kidnapping and other vices became the order of the day in Nigeria, Shed (2011). Two sets of individual actors were indicted as engaging in corrupt activities that led to the fuel subsidy scam and crisis. These are the petroleum marketers who made claims that they supplied fuel but it was later discovered that none was supplied. They were paid for unsupplied fuel and the public suffered for this scam. The second set of indicted actors were officers of the Ministry of petroleum who gave licenses to individuals who did not have any petrol distribution stations and paid them for unsupplied claims from public revenue. Nigerians suffered and paid higher prices when the subsidy was removed. These individuals exhibited a public behavior system that demonstrated an ethical loss of human values, a loss that is unmistakably un-African, un-philosophical, un-religious and un-ethical as run counter the basic tenets of theistic humanism of professor Dukor's propositions in his new African philosophy. The Church, in keeping with its valuere-orientation mandate in African philosophy and the fundamental framework of theistic humanism, came out publicly during the crisis to create an environment for peace-building to take place and save the day from degenerating into another "Arab spring" in Nigeria.

\section{The Role of the Church in Alleviating the Negative Effect of the Subsidy Removal on the Masses}

Religion is noted for its ability to diffuse tension when things go wrong. According to Okwueze (2012: p. 60), "religious leaders cannot keep mute at a time when social change is nothing but that which is achievable within the framework of traditionally conservative norms, and when political and economic developments are regarded as foolish ventures". Therefore, during all these crisis period, the church played a lot of responsible roles which helped to caution the effect of the riots and the roles are as follows:

1) Prayers of intercession were said in almost all the churches in Nigeria, asking for God's intervention.

2) Some churches brought out palliative measures for their members to help cushion the effects of the subsidy removal. Examples are, buses were brought out at no cost to take worshippers to churches and back home after service.

3) The clergies made it a point of duty to preach on the positive and negative effects of the subsidy, warning the people not to be violent about the government's decision.

4) During the period and till date, some religious organizations are still giving out alms to the less privileged to help them take care of their immediate needs.

5) Through organized public preaching during the street protests and strikes, a good number of people changed their thoughts concerning the fuel subsidy. Okwueze (2012: p. 97) asserted that religion no doubt influences the thought processes of an individual as a person's religious view and beliefs could control an individual in many different ways. Religion is a strong unifying factor in the society. The followers always believe in the preaching of their clergies. The church played a major role to see that there was peace throughout the period of fuel subsidy removal and that the sometime violent street protests did not eventually generate anarchy and instability in the country.

\section{Summary}

There is no doubt that there could be some possible advantages coming out of the removal of the subsidy on petroleum products in Nigeria. There could be improvements in infrastructures, healthcare, education etc. There is also an understanding among Nigerians that the government has the authority and power to enact and implement policies that would promote the common good for the welfare of the masses. But the crux of the matter is the crisis of confidence that characterize the relationship between the government and the common man on the street. Crisis of confidence exists where no iota of truth is vested on the government following the previous government failures to implement other magnified policies. A good number of reasons abound why the lack of confidence exists. For instance, the removals of subsidy on gas, yet Nigerians have not seen the impact of the removal. According to Guardian newspaper of 28th December (2011), Agbon, explained that, the "true cost of one litre of petrol in Nigeria is around N34, 03". It is certainly less than the official price of N65 per litre. His logic is sound, since the true price of petrol using government figure is around N34.03 per litre, therefore, there is no petrol subsidy. Rather there are high sales of $91 \%$ at current prices of N65 per litre. In other words, a litre of fuel in Nigeria is not more than N40.00.

\section{Recommendations}

The Government has strong argument to support its policy changes, to a certain extent they can be justified, but the Government must now deliver on its promise to its people in order to regain its credibility. This is not the first time oil subsidy has been removed in the country, and it is not the first time the Government has committed to investing the subsidy funds into social amenities such as health, education, and much needed infrastructure in various sectors such as transport and power. Nigerians are now completely disillusioned with the empty promises, and are closely watching the Government's next steps. It is because of this that we outline these recommendations.

1) A starting point for the Government will be to focus on repairing its rundown refineries and bringing an end to the senseless system of importing $85 \%$ of the oil needed for its own domestic consumption.

2) It needs to learn lessons from other more developed oil producing countries. The issue of the exorbitant salaries of legislators should be properly addressed. According to Roseline Okereke in Guardian Newspaper of 14th July (2012), Nigerian legislators are among the highest paid in the world. The disconnect between the minimum income of N18, 000 (\$118) and the average salary of a senator in Nigeria is N15.18m $(\$ 99,167)$ per month is completely unjustified and unjust. With GDP per capita of $\$ 2500$, Nigeria is classified as one of the poorest countries in the world. Yet its legislators' salaries are more than those of their counter parts in USA, UKs, France and Sweden.

3) Nigerian Government must invest in its people and focus on addressing the country's huge economic problems, provid- 
ing jobs and basic social amenities such as good education, healthcare, and much needed infrastructure. The government should also tax high income individuals' in order to raise revenues for urgent pro-poor investments and a fairer society.

4) The Government must also focus on the security challenges facing the country under the guise of ethno-political and pseudo-religious movement. USIP, in recent article related to the subsidy removal; stated that "severe domestic economic shocks in conflict-affected countries, like Nigeria, could have dire and potentially destabilizing socio-economic consequences.

5) The government should also provide a functional railway for its citizens, with this; traffic jam will reduce and therefore, will go a long way impacting on the commercial activities of those in the hinterland. Formally, the Nigeria Corporation Railway (NRC) was among the parastatals that could be ranked as the highest employer of labour in the country. Not just providing job, Nigerian Railway Corporation was initially a major means of transportation which has helped tremendously in reducing the prices of goods and commodities in the market.

6) The removal of fuel subsidy should not be a bad thing, but certain things ought to have been in place before government takes the step. Removing oil subsidy is not a problem; the problem is to plough back the revenue that will accrue from it into critical areas. The money from the subsidy should be managed so that the masses can have their own benefits either directly or indirectly.

\section{Conclusion}

The problem of the nation is not oil subsidy or inadequate revenue generation. The problem is actually that the ones generated are diverted into private hands and pockets in corruption enrichment. Example, the case of (Farouk and Otedola) in Sun Newspaper of July 9th 2012. The religious clerics both in the churches and mosques have repeatedly preached against it. Also, there is no basis for Nigeria not to have built a new refinery since 1984. Part of the money from the subsidy should be used in building new refineries.

There is so much to be learnt from the reactions of the masses in the fuel subsidy removal. These include the need for government to carry the people along its policies. Government should realize that it holds power in trust for the people and any decision or policy taken without their support will meet a strong opposition. Therefore, trust is indispensable in governance. There is urgent need to fast-track the Petroleum Industry Bill (PIB). The Bill seeks to, among other things; remove the entire bottle-necks that hamper an effective deregulation of the oil sector.

Most importantly, the government should bear in mind that the gods are the watch-dogs of the societal morality. Thus, this was agreed by Dukor (2010),

That the existential pragmatic culture of the Africans lies in their closeness to nature and living by the dictates of natural law and gods. The gods are guardian of societal morality, though God is ultimate. The people try as much as possible not to commit any offence against their gods. Or society for that would bring metaphysical evil. The gods are the watchdogs of the societal morality and law ... gods are involved as witnesses to any event, bond or agreement.

Therefore, those who divert oil money meant for 100 million
Nigerians should have a rethink and to remember that theistic humanism has both religio-ethical implications for the stability and sustainable development of the African society as it shows that corrupt anti-social activities or policies are against the fundamental human values for which African philosophy has become renowned as an emerging discipline.

\section{REFERENCES}

Achebe, C. (1983). The trouble with Nigeria. Enugu: Fourth Dimension Publishers.

Adeola, A. (2012). Aderinola. URL (last checked 12 July 2012). http://Wordpress.com

Afonne, E. (2011). Politics of oil subsidy: The cartels fraudulent acts. News World, 24 October.

Ahmaddiya, A. C. (2012). Ahmaddiya decries fuel subsidy removal. The Guardian, 5 January 2012, 13.

Akhine, et al. (2012). The Guardian, 5 January 2012, 4.

Akinloye, L. (2012). Gone for good. Nigeria Fuel Subsidy, January 2012, Article 4.

Boko, H. (2012). 3 days ultimatum from their leaders. PM News, Published 3 January 2012.

Chuta, S. C. (2004). Corruption in Nigeria. Nsukka: Afro-Orbit Publishers.

Daily Sun Newspaper (2012). 9th July 2012, 2.

Dukor, M. (2010). African philosophy in the global village: Theistic panpsychic rationality, axiology and science. Brussels: LAMBERT Academy.

Ewuim, N. C. (2004). Theory and practice of community and rural development. Onitsha: Rex Charles and Patrick Ltd.

Ezeani, E. O. (2012). Delivering the goods. Nsukka: University of Nigeria Nsukka.

Igwe, S. C. (2010). How Africa underdeveloped Africa. Port Harcourt: Professional Printers.

Isah, A. (2009). Sultan cities hunger, poverty in Jos crisis. The Fulani Cattle Breeders, the Insider, Magazines, June 15.

Ituma, E. A. (2008). The significance of christian youth development in eradicating corruption in Nigeria (pp. 41-52). In C. O. Ugwu (Ed.), Luke: Nsukka Journal of Religion Studies.

Lawson, A. (2012). The mace voice of democracy. Fuel Subsidy Removal: The Challenge before House Committee on Petroleum Downstream. Punch Newspaper on 18th March 2012.

Mbiti, J. S. (1969). Africa philosophy and religion. The York: Praeger.

Newsdiaryonline.com/illegal removal (2010). Campaign manifesto for presidential election, 18th September 2010.

Newspaper (2012). Published on 4th July.

Obasa, F. (2012). Fuel subsidy removal. The Arguments and paths to progress, -Nigeria-oil-and-Gas monthly, URL (last checked 23 February 2012). http/www.nigerianonlinegas.com/pg=769

Obasi, N. K. (2003). Foreign participate in the Nigeria oil and gas industry. URL (last checked 26 December 2011).

http://www.onlinenigeria.com/links/adv.asp?Blurb $=493$

Okereke, R. (2012). Business services industry watch. The Guardian.

Onajemo, O., Collins, O., Nkechi, O., \& Abosed, M. (2012). Fuel subsidy removal not to punish Nigerians says FG. Abuja: Punch.

Onoho, B. E. (2012). Many imponderables of petroleum subsidy. Guardian Newspaper, 8 January 2012.

Onoho'Omhem, E. (2012). Subsidy and security palaver. The guardian, 8 January 2012.

Ori, O. (2012). Railwaste, 28 January 2012.

Oxford Advanced Learners Dictionary (1990). 123.

Peace and Conflict Monitor (University for Peace) (2012). Nigeria fuel Subsidy Removal and National Crisis by Fatima Kyari Mohammed.

Raymond, G. (2012). Subsidies and sufferings in Nigeria: Exploring conflict-sensitive economic policy in Fragile State, United States Institute for Peace. URL (last checked 16 January 2012).

http://inec.usip.org/blog/2012/jan/16/Subsidies-and-Suffering-NigeriaExploring-Conflict-Sensitive-Economic-Policy-Fragile

Sachs, J. S. (2012). Nigeria hurtles into a tense crossroad. New York 


\section{T. NWAOGA, K. C. ANI CASIMIR}

Times. URL (last checked 10 January 2012).

http://www.nytimes.com/2012/01

Shed, F. (2011). Fuel subsidy removal: The government vs the people. URL (last checked 14 December 2011).

http://www.nigeriavillagesquare.com/Guest-articles/fuel-subsidy-rem oval-the-government-vs-the-people

Son, G. (2011). Nigeria: The case against removal of fuel subsidy and the argument for deregulation petroleum subsector. URL (last checked 26 December 2011).

http://www.awarenessfordevelopment.org/index.php?option=comcon tent\&view $=$ article $\&$ id $=66$ : Nigeria-fuel-subsidy

Ugochukwu, O. C. (2012). The implications and alternatives to fuel subsidy removal. Vanguard Newspaper, 9 January 2012.

www.Wikipedia.com/standard of living

Yields on Fuel Subsidy (2012). Financial times.

http://www.ft.com/tt/cons 